\title{
New Books Published by Springer and Taylor \& Francis-CRC Press
}

DOI: $10.1134 / \mathrm{S} 1061934810030202$

Green Fluorescent Protein. Series: Topics in Fluorescence Spectroscopy, J.R. Lakowicz and C.D. Geddes, Eds., Springer, 2008, vol. 12, 320 pp.

Inorganic Membranes for Energy and Fuel Applications, A.C. Bose, Ed., Springer, 2008, 210 pp.

M. Gey, Instrumentelle Analytik und Bioanalytik: Biosubstanzen, Trennmethoden, Strukturanalytik, Applikationen (Instrumental Analytics and Bioanalytics: Biosubstances, Separation methods, Structural Analytical Chemistry Applications), Springer, 2008, $460 \mathrm{pp}$.

Detection of Liquid Explosives and Flammable Agents in Connection with Terrorism, H. Schubert and A. Kuznetsov, Eds., Springer, 2008, 275 pp.
J.R. Lakowicz, Principles of Fluorescence Spectroscopy, Springer, 2006, 3rd ed., 954 pp.

A. Rodgman and T.A. Perfetti, The Chemical Components of Tobacco and Tobacco Smoke, Taylor \& Francis-CRC Press, 2008, 928 pp.

G. Hanrahan, Environmental Chemometrics: Principles and Modern Applications, Taylor \& FrancisCRC Press, 2008, 320 pp.

Ionic Liquids in Chemical Analysis, M. Koel, Ed., Taylor \& Francis-CRC Press, 2008, 456 pp.

C.V.A. Duke and C.D. Williams, Chemistry for Environmental and Earth Sciences, Taylor \& FrancisCRC Press, 2007, 247 pp.

N.B. Zorov 